\title{
Influence of placentally mediated fetal growth restriction on the onset of puberty in male and female lambs
}

\author{
P. Da Silva ${ }^{1}$, R. P. Aitken ${ }^{1}$, S. M. Rhind ${ }^{2}$, P. A. Racey ${ }^{3}$ and \\ J. M. Wallace ${ }^{1 *}$ \\ ${ }^{1}$ Rowett Research Institute, Bucksburn, Aberdeen AB21 9SB, UK; ${ }^{2}$ Macaulay Land Use \\ Research Institute, Craigiebuckler, Aberdeen AB15 8QH, UK; and ${ }^{3}$ Department of Zoology, \\ University of Aberdeen, Aberdeen AB24 2TZ, UK
}

The onset of puberty in prenatally growth-restricted versus normally grown lambs of both sexes, born in April and housed under natural photoperiod, was examined. Singleton pregnancies were established and adolescent ewes were offered a high or moderate nutrient intake throughout gestation. Placental mass was reduced $(\boldsymbol{P}<\mathbf{0 . 0 0 1})$ in high compared with moderate intake dams and resulted in the birth of growth-restricted and normal birth weight offspring, respectively. At birth, female lambs weighed $3.43 \mathrm{~kg}$ versus $5.03 \mathrm{~kg}(P<0.001 ; n=14$ per group) and male lambs weighed $2.75 \mathrm{~kg}$ versus $5.18 \mathrm{~kg}$ $(P<0.001 ; n=7$ per group) in growth-restricted and normal birth weight groups, respectively. Lambs suckled for 12 weeks and thereafter were fed ad libitum until week 43 of age. Growth-restricted lambs had lower preweaning live weight gains and this difference was more pronounced in

\section{Introduction}

In humans, impaired growth during fetal life is associated with increased risk of reproductive disorders such as ovarian cancer (Barker et al., 1995), premature menopause (Te Velde, 1993), testicular cancer (Brown et al., 1986; Møller and Skakkebæk, 1997), cryptorchidism (Depue, 1984; Jones et al., 1998) and decreased semen quality (Francois et al., 1997). These epidemiological studies indicate that environmental factors such as maternal nutrition, which influences the prenatal growth trajectory and physiology of the major organ systems of the body (Hay, 1998; Robinson et al., 1999), may also programme persisting changes in the fetal reproductive axis that may, in turn, explain infertility of the offspring in later life. The results of animal studies indicate that postnatal reproductive ability may be largely determined by appropriate development of the hypothalamic-pituitary-gonadal axis during fetal life (Brooks et al., 1996). For example, pharmacological inhibition of fetal gonadotrophin secretion from mid-gestation onwards

*Correspondence

Email: Jacqueline.Wallace@rri.sari.ac.uk male $(P<0.05)$ than in female lambs $(P=0.07)$. Thereafter, live weight remained lower $(P<0.05)$ in growth-restricted than in normally grown lambs of both sexes until week 25 of age. In females, the time of onset of puberty was similar in the two groups. All females ovulated and there were no differences in the number of ovarian cycles recorded or in the incidence of aberrant ovarian function. In males, testosterone concentrations and testicular volume were lower in growth-restricted compared with normally developed lambs from birth until weeks 28 and 35 of age, respectively $(P<0.05)$. The seasonal increase in plasma testosterone concentrations occurred later in growthrestricted than in normally developed lambs $(P<0.01)$ but the timing of maximum peak concentrations was similar. Peak testosterone concentrations were lower $(P<0.05)$ in growth-restricted than in normal male lambs. reduces plasma testosterone concentrations in lambs at week 28 of age (Thomas et al., 1995).

At present, very little is known about the reproductive consequences of nutritionally induced prenatal growth restriction on the onset of puberty in lambs. There is evidence that maternal undernutrition $(0.6 \times$ maintenance $)$ from day 30 of pregnancy has an adverse effect on pituitary responsiveness to $\mathrm{GnRH}$ in prepubertal lambs at day 55 of age (Deligeorgis et al., 1996), which, in turn, may modify the time of onset of puberty. After birth, it has been demonstrated that growth-related cues are important modulators of gonadotrophin secretion as indicated by hypogonadotrophism during periods of radically reduced feed intake in domestic sheep breeds (Foster et al., 1985; Adam et al., 1998) and humans (Judd, 1998). In the nutritionally growth-restricted lamb model developed by Foster et al. (1985), prolonged undernutrition after weaning prevented the initiation of reproductive activation at the normal age (Suttie et al., 1991). Their evidence supports a causal relationship between postnatal cues that relate information about physiological size and nutrition, and pubertal reproductive activation (Foster, 1994), provided that the lambs experienced an appropriate photoperiod (Foster, 1983). 
Using a highly controlled experimental paradigm, Wallace et al. (1996) showed that overnourishing adolescent sheep throughout gestation results in a major restriction in placental growth and, hence, has a profoundly negative influence on lamb birth weight. This paradoxical event occurs because high maternal nutrient intakes promote a major anabolic drive to maternal tissue synthesis at the expense of the evolving nutrient requirements of the gravid uterus (Wallace et al., 1997, 1999). In the present study, this model was used to investigate whether this form of nutritionally mediated fetal growth restriction programmes alterations in the reproductive axis that affect the onset of puberty in female and male lambs.

\section{Materials and Methods}

\section{Animals and experimental design}

All the procedures were licensed under the UK Animals (Scientific Procedures) Act of 1986. Embryos recovered on day 4 after oestrus from superovulated adult ewes (Border Leicester $\times$ Scottish Blackface) that had been inseminated by a single sire (Dorset Horn) were individually transferred synchronously into the uteri of adolescent recipient ewe lambs (Dorset Horn $\times$ Mule) as described by Wallace et al. (1997). All animals were housed in individual pens under natural lighting conditions at the Rowett Research Institute $\left(57^{\circ} \mathrm{N} 2^{\circ} \mathrm{W}\right)$. Recipient ewes were approximately 7 months old with a mean live weight of $46 \mathrm{~kg}(n=42)$. Immediately after embryo transfer, adolescent ewes were allocated evenly to one of the two dietary treatments based on live weight, body condition score (Russel et al., 1969) and ovulation rate at the time of embryo transfer. Recipient ewes were offered individually a high or a moderate level $(n=21$ per group) of a complete diet calculated to promote rapid or normal maternal growth rates, respectively. The aim in the moderate intake group was to maintain a moderate growth rate of approximately $75 \mathrm{~g}^{\text {day }^{-1}}$ during the first 100 days of pregnancy. The diet provided an estimated 10.2 MJ metabolizable energy $\mathrm{kg}^{-1}, 136.6 \mathrm{~g}$ crude protein $\mathrm{kg}^{-1}$ and had an average dry matter of $85.5 \%$. The diet comprised $30 \%$ $(\mathrm{w} / \mathrm{w})$ finely milled hay, $50 \%(\mathrm{w} / \mathrm{w})$ barley, $10 \%(\mathrm{w} / \mathrm{w})$ molasses, $9 \%(\mathrm{w} / \mathrm{w})$ fishmeal, $0.3 \%(\mathrm{w} / \mathrm{w})$ salt, $0.5 \%(\mathrm{w} / \mathrm{w})$ dicalcium phosphate and $0.2 \%(\mathrm{w} / \mathrm{w})$ of a vitamin-mineral supplement. All ewes were offered their feed in two equal portions at 08:00 $\mathrm{h}$ and 16:00 $\mathrm{h}$ daily and the daily feed refusal was weighed and recorded before the 08:00 $\mathrm{h}$ feed. Moderate intake ewes were offered their experimental diets immediately after embryo transfer, whereas the level of food offered to high intake ewes was increased gradually over a 2 week period until the level of daily feed refusal was approximately $15 \%$ of the total offered. Ewes were weighed weekly and their body condition score was assessed monthly throughout gestation. The level of feed offered was reviewed and adjusted three times a week on the basis of both change in live weight data and feed refusals. After day 100 of gestation the feed intake of the moderate intake ewes was increased weekly to meet the estimated increasing demands of the developing fetus during the final third of gestation.

\section{Pregnancy outcome and neonatal care procedures}

Pregnancy outcome was determined after spontaneous vaginal delivery at term. The lambs were born during a 10 day period in April. Lambs were dried and weighed after delivery and the time, date of birth and sex were all recorded. All lambs were injected (s.c.) with antibiotic (Baytril 5\%; $50 \mathrm{mg} \mathrm{ml}^{-1}$ at $0.1 \mathrm{ml} \mathrm{kg}^{-1}$ body weight; Bayer) at birth and daily for a further 4 days thereafter.

Ewe colostrum yield was measured before lamb suckling and within $30 \mathrm{~min}$ of parturition. After i.v. injection of oxytocin (Oxytocin-S; 6 iu per ewe; Intervet Ltd, Cambridge), the ewes were milked by hand until all the colostrum had been removed from the udder. The colostrum was weighed and fed to the lamb at a rate of approximately $50 \mathrm{ml} \mathrm{kg}^{-1}$ body weight using a bottle or stomach tube. In cases where the dam had insufficient colostrum, frozen ewe colostrum harvested from optimally nourished dams during other studies was used.

After the placenta was delivered, it was weighed and the fetal cotyledons were dissected, counted and weighed. After delivery, maternal feed intake was increased progressively to sustain the needs of the 12 week lactation period.

\section{Postnatal lamb management}

The lambs were housed under natural photoperiodic conditions throughout postnatal life. They were allowed to suckle their dams for 12 weeks and then weaned. At 2 weeks of age a pelleted creep feed was introduced, ad libitum, to supplement the mother's milk and the lambs also had access to the complete diet of their mothers. The pelleted diet prepared at the Rowett Research Institute comprised $90 \%(\mathrm{w} / \mathrm{w}$ ) barley, $8.42 \%(\mathrm{w} / \mathrm{w})$ fishmeal, $1.28 \%$ $(\mathrm{w} / \mathrm{w})$ limestone, $0.2 \%(\mathrm{w} / \mathrm{w})$ salt and $0.1 \%(\mathrm{w} / \mathrm{w})$ vitaminmineral supplement (Norvite, Insch). At weaning, lambs received a combination of creep feed and a complete diet and were transferred gradually onto a $100 \%$ complete diet over a 2 week period. This complete diet was of the same composition as that fed to the pregnant dams and was offered ad libitum. Feed offered and daily feed refusal were recorded individually for male lambs only, as female lambs were penned in groups at week 20 of age to facilitate daily detection of oestrus. Females were exposed to ram pheromones in the sheep facility from birth onwards and both birth weight categories were represented in each of the group pens. All female and male lambs were weighed weekly throughout the study period.

From birth to week 43 of age, blood samples were collected by jugular venepuncture three times a week from female lambs and once a week from male lambs.

\section{Onset of puberty}

The measurements of plasma progesterone concentration taken three times a week and daily detection of 
oestrus from week 20 of age onwards were used to determine the time of onset of ovarian function (puberty) and oestrous behaviour in ewe lambs born to high or moderate intake dams $(n=14$ per group). Raddled vasectomized rams were used to detect oestrous behaviour in the ewe lambs. For each of the 28 ewe lambs, time from birth to the onset of cyclic ovarian activity and to first behavioural oestrus, duration of the first normal ovarian cycle, number of luteal phases (for cyclic ewe lambs), occurrence and duration of persistent corpora lutea and duration of the breeding season (for ewes that became seasonally anoestrous by the end of the 43 week study period) were recorded.

Plasma testosterone concentrations and testicular size were used as indices of the time of onset of puberty in male lambs born to high intake compared with moderate intake dams ( $n=7$ per group). Testes were measured weekly using Vernier callipers (Baty; RS components Ltd, Corby). The volume of the left testis was estimated using measurements of diameter at the widest portion and length was estimated by assuming that it was a prolate spheroid (Chandrasekhar et al., 1985) according to the formula: volume $\left(\mathrm{cm}^{3}\right)=$ $\left((1 / 6) \times 3.14 \times a^{2} \times b\right) / 1000$ where $a=$ diameter at largest circumference and $b=$ length of the testis). The volume of the testis was then expressed as a ratio to live weight.

\section{Radioimmunoassays}

Concentrations of progesterone and LH were measured in duplicate aliquots of plasma by radioimmunoassays as described by McNeilly et al. (1986) and Ronayne and Hynes (1990). Concentrations of testosterone were measured using a radioimmunoassay (Corker and Davidson, 1978) modified for an iodinated tracer (Sharpe and Bartlett, 1985). The sensitivities of the assays were $0.2 \mathrm{ng} \mathrm{ml}^{-1}$ for progesterone, $0.3 \mathrm{ng} \mathrm{ml}^{-1}$ for $\mathrm{LH}$ and $0.013 \mathrm{ng} \mathrm{ml}^{-1}$ for testosterone. The inter- and intra-assay coefficients of variation were $12.6 \%$ and $6.1 \%$ for progesterone, $10.6 \%$ and $10.0 \%$ for $\mathrm{LH}$, and $13.5 \%$ and $12.6 \%$ for testosterone.

\section{Statistical analyses}

Endocrine puberty was defined for the ewe lambs as the first increase in plasma progesterone concentrations $\geqslant 1 \mathrm{ng} \mathrm{ml}^{-1}$ that was followed by at least two more consecutive high values. For male lambs, endocrine puberty was defined as a sustained increase (at least two high values) in plasma testosterone concentrations to $>2 \mathrm{ng} \mathrm{ml}^{-1}$. In addition, the individual plasma testosterone concentrations were analysed in 7 week periods and the overall treatment means calculated. Two of seven normal birth weight male lambs were killed at week 25 of age owing to severe carpal bursitis and, thereafter, statistical analyses were based on five normal birth weight and seven growth-restricted lambs.

Group means were compared using Student's $t$ test. Lamb birth weight and weaning weights were subjected to ANOVA (General Linear Models) to analyse the effects of maternal nutritional treatment, sex and the interaction between the two parameters. Correlation analysis was carried out by Pearson's product moment test where appropriate.

\section{Results}

\section{Maternal feed intakes and changes in live weight}

Mean maternal feed intakes (kg per week) were higher in high intake compared with moderate intake dams at days 5-50 (13.9 \pm 0.6 versus $6.6 \pm 0.1 ; P<0.001), \quad 50-100$ (13.9 \pm 0.6 versus $6.1 \pm 0.1 ; P<0.001)$ and $100-140$ $(14.2 \pm 0.5$ versus $9.3 \pm 0.1 ; P<0.001)$ of gestation. At the time of embryo transfer, high and moderate intake adolescent dams had similar mean live weights $(45.0 \pm 0.7$ versus $47.7 \pm 1.1 \mathrm{~kg}$, respectively) and body condition scores $(2.1 \pm 0.1$ versus $2.2 \pm 0.1$ score units, respectively). At day 140 of gestation the mean live weights were $85.9 \pm 2.2$ and $69.1 \pm 0.9 \mathrm{~kg}$ in high and moderate intake dams, respectively, and mean body condition scores were $3.0 \pm 0.1$ and $2.1 \pm 0.1$ score units, respectively $(P<0.001)$.

\section{Pregnancy outcome}

Mean duration of gestation, lamb birth weights, placental masses, total fetal cotyledon masses and colostrum yields from high and moderate intake dams are shown (Table 1). Mean placental mass data for the high intake group were calculated for 18 rather than 21 animals as three dams failed to shed the entire placenta at parturition. High nutrient intakes throughout pregnancy were associated with decreased duration of gestation $(P<0.001)$, decreased placental mass $(31 \%, P<0.001)$ and decreased lamb birth weight $(37 \%, P<0.001)$. The lambs produced by high intake dams are designated as growth-restricted and those produced by moderate intake dams as normal birth weight lambs. The birth weight of lambs produced by high intake dams was significantly lower than the birth weight of lambs from moderate intake dams (male lambs: $47 \%$ reduction in birth weight $(P<0.001)$; female lambs: $32 \%$ reduction in birth weight $(P<0.001)$; Table 1$)$ but there was a nonsignificant interaction between maternal nutritional treatment and sex of the lamb on birth weight $(P=0.08)$. Colostrum yield measured before suckling was significantly lower $(P<0.001)$ in high intake compared with moderate intake dams (Table 1).

\section{Lamb body weight characteristics}

Irrespective of sex, growth-restricted spring-born lambs were significantly lighter at weaning (12 weeks of age) compared with normal birth weight lambs $(29.3 \pm 1.0$ versus $33.9 \pm 0.9 \mathrm{~kg}$, respectively; $P<0.01)$. Irrespective of maternal nutritional treatment, lamb live weight at weaning was positively correlated with birth weight $(r=0.437$, $n=42, \quad P<0.01)$. At weaning, there was a significant interaction $(P<0.05)$ between maternal nutrition and sex of 
Table 1. Duration of gestation, lamb birth weight, placental mass, fetal cotyledon mass and colostrum yield in high and moderate nutrient intake dams

\begin{tabular}{lcc}
\hline & \multicolumn{2}{c}{ Maternal nutrient intake } \\
\cline { 2 - 3 } & $\begin{array}{c}\text { High intake } \\
(n=21)\end{array}$ & $\begin{array}{c}\text { Moderate intake } \\
(n=21)\end{array}$ \\
\hline Characteristic & $142.6 \pm 0.6$ & $146.3 \pm 0.8^{*}$ \\
Duration of gestation (days) & $3.20 \pm 0.16$ & $5.08 \pm 0.16^{*}$ \\
Lamb birth weight (kg) & $3.43 \pm 0.18$ & $5.03 \pm 0.23^{*}$ \\
Females $(n=14$ per group) & $2.75 \pm 0.24$ & $5.18 \pm 0.22^{*}$ \\
Males $(n=7$ per group) & $294 \pm 21^{\text {a }}$ & $429 \pm 28^{*}$ \\
Total fetal cotyledon mass (g) & $62 \pm 3^{\text {a }}$ & $119 \pm 10^{*}$ \\
Colostrum yield (ml) & $155 \pm 28$ & $317 \pm 35^{*}$ \\
\hline
\end{tabular}

Values are mean \pm SEM.

${ }^{\mathrm{a}} n=18$.

*Significantly different from corresponding high intake value $(P<0.001)$.

the lamb with respect to lamb live weight. Mean daily live weight gain during the 12 week suckling period was lower in growth-restricted compared with normal grown male lambs $\quad\left(304 \pm 22\right.$ versus $376 \pm 17$ g day $\left.^{-1} ; \quad P<0.05\right)$. During the same period, a lower rate of live weight gain was also observed in growth-restricted female lambs compared with normal grown female lambs but was not significant $\left(311 \pm 11\right.$ versus $343 \pm 13$ g day $\left.^{-1}\right)$. In females, mean live weight was lower in prenatally growth-restricted compared with normal birth weight lambs at 15 (35.5 \pm 1.3 versus $38.7 \pm 0.9 \mathrm{~kg} ; P<0.05), 20(42.4 \pm 1.2$ versus $45.8 \pm 0.9 \mathrm{~kg}$ $P<0.05)$ and $25(47.6 \pm 1.4$ versus $51.2 \pm 1.1 \mathrm{~kg} ; P<0.05)$ weeks of age (Fig. 1a). Daily live weight gain from week 15 to week 25 of age was $174 \pm 14$ and $180 \pm 10$ g day $^{-1}$ in growth-restricted and normal birth weight lambs, respectively; this difference is not significant.

The mean weekly live weights of male lambs after weaning are shown (Fig. 1b). Growth-restricted male lambs remained lighter $(P<0.01)$ than normal grown lambs until week 25 of age. Thereafter, two normal birth weight lambs were killed and, despite the fact that mean live weight remained higher, the increased variability in both groups meant that the difference in live weight between the two groups was no longer significant. Daily live weight gain from week 15 to week 25 of age was $225 \pm 22$ and $192 \pm 9$ g day $^{-1}$ for growth-restricted compared with normal birth weight lambs, respectively.

There was no significant difference in the feed intakes of male lambs from week 12 of age onwards.

\section{Onset of puberty: female lambs}

Mean weekly plasma LH concentrations increased from the first week of age but a decrease occurred at weeks 5 and 7 of age for normally developed and growth-restricted lambs, respectively (Fig. 2a). Growth-restricted lambs generally had higher plasma $\mathrm{LH}$ concentrations than (a)

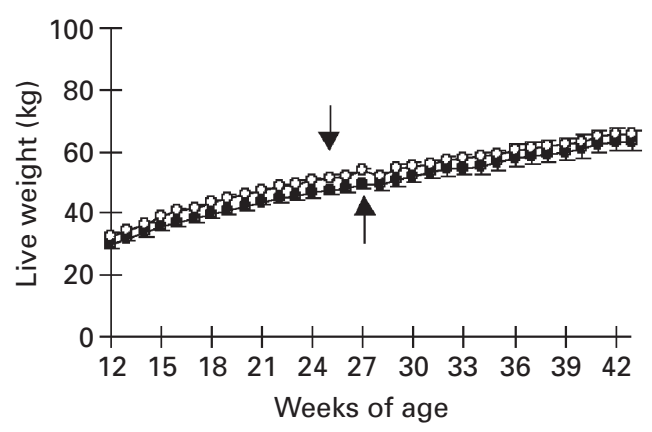

(b)

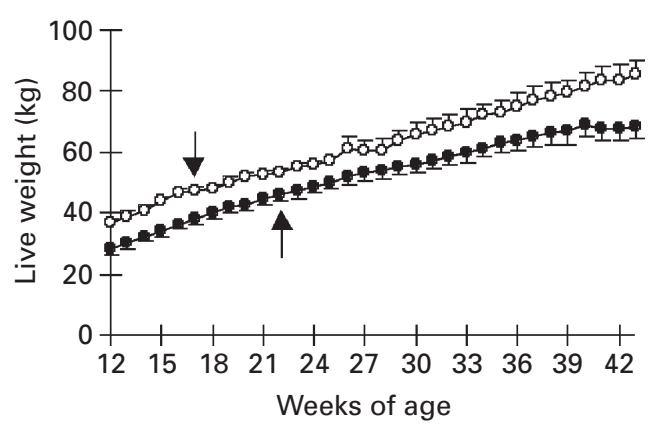

Fig. 1. Weekly live weights from week 12 to week 43 of age for growth-restricted $(\bullet)$ and normally developed $(O)$ (a) female and (b) male lambs. Values are mean \pm SEM (female: $n=14$; male: $n=$ 7 up to week 25 and $n=5$ thereafter). Arrows indicate the times of mean onset of puberty.

normally developed female lambs but this difference was only significant at weeks 2, 10, 15, 17 and 20 of age $(P<0.05)$.

The mean age of onset of endocrine ovarian function (puberty), as determined by plasma progesterone analysis three times a week, was not significantly different in growthrestricted compared with normally developed spring-born female lambs (Table 2). The duration of the first normal ovarian cycle was not significantly different between growth-restricted and normal birth weight ewe lambs and there were no differences in the number of ewe lambs in each group that had normal or aberrant ovarian cyclicity (Table 2). Patterns of plasma progesterone concentrations in representative ewe lambs that showed regular ovarian cyclicity or had persistent corpora lutea are shown (Fig. 3). The mean number of ovarian cycles recorded in cyclic ewe lambs was similar in the growth-restricted and normally developed groups (Table 2). Two ewes in each group had a persistent corpus luteum after ovulation: at days 185 and 281 of age for growth-restricted females, and at days 54 and 178 of age for normally developed females. One growthrestricted ewe lamb underwent only one ovarian cycle during the period of blood sampling (at day 211 of age). 
(a)

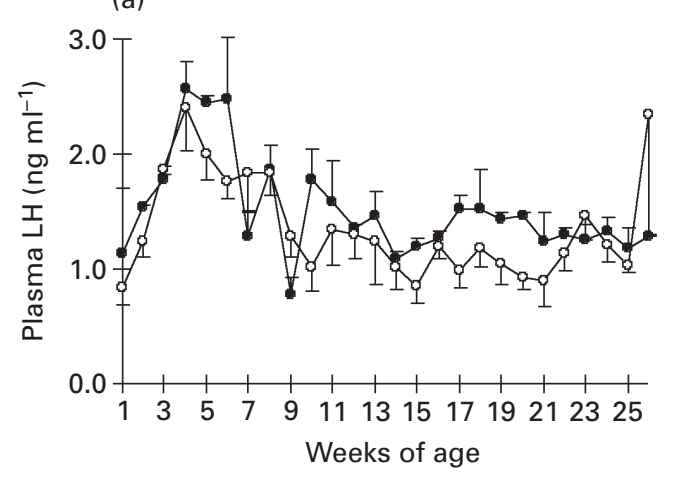

(b)

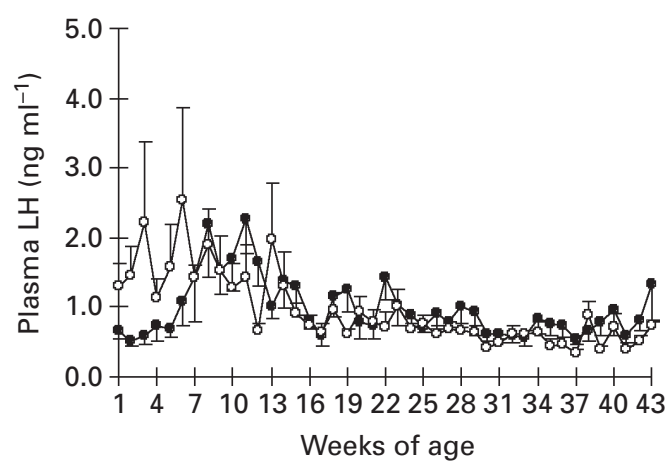

Fig. 2. Weekly plasma LH concentrations in growth-restricted and normally developed $(O)$ (a) female and (b) male lambs. Values are mean \pm SEM (female: $n=14$; male: $n=7$ up to week 25 and $n=5$ thereafter).

There were no significant differences in the duration of the breeding season for ewes that became seasonally anoestrous within the study period (Table 2).

There were no differences in live weight at the time of onset of puberty between growth-restricted and normally developed ewe lambs (48.5 \pm 1.5 versus $49.6 \pm 2.5 \mathrm{~kg}$, respectively). Irrespective of growth status, there was no relationship between birth weight and live weight at the onset of puberty $(r=0.310, n=28, P>0.05)$ and between lamb birth weight and age at the onset of puberty ( $r=-0.016, n=28, P>0.05)$.

Three of 14 ewe lambs in each group did not show behavioural oestrus. Two of the three growth-restricted ewe lambs that did not show overt oestrous behaviour had persistent corpora lutea. The other growth-restricted ewe lamb showed normal ovarian cyclicity. All three normally developed ewe lambs that did not show behavioural oestrus had normal ovarian activity. For the remaining 11 ewe lambs in each group, time from birth until detection of first behavioural oestrus was $194 \pm 9$ and $205 \pm 10$ days for growth-restricted and normally developed ewe lambs, respectively.
Table 2. Age at onset of puberty, number and normality of cycles and duration of the breeding season in growth-restricted and normal spring-born ewe lambs

\begin{tabular}{lcc}
\hline & \multicolumn{2}{c}{ Nutritionally induced growth status } \\
\cline { 2 - 3 } Characteristic & Growth-restricted & Normal \\
\hline $\begin{array}{l}\text { Age when ovulation began (days) } \\
\text { (range) }\end{array}$ & $\begin{array}{c}190 \pm 4 \\
(167-211)\end{array}$ & $\begin{array}{c}177 \pm 11 \\
(54-229)\end{array}$ \\
$\begin{array}{l}\text { Duration of first ovarian } \\
\text { cycle (days) }\end{array}$ & $16.7 \pm 1.0$ & $18.2 \pm 1.0$ \\
$\begin{array}{l}\text { Number of ewe lambs exhibiting } \\
\text { aberrant ovarian cyclicity }\end{array}$ & 3 & 2 \\
$\begin{array}{l}\text { Number of ewe lambs exhibiting } \\
\text { normal ovarian cyclicity }\end{array}$ & 11 & 12 \\
$\begin{array}{c}\text { Number of ovulatory cycles per } \\
\text { first season }\end{array}$ & $6.2 \pm 0.6$ & $5.7 \pm 0.6$ \\
$\begin{array}{c}\text { Duration of first breeding } \\
\text { season (days) }\end{array}$ & $100 \pm 12$ & $110 \pm 11$ \\
\hline
\end{tabular}

Values are mean $\pm \operatorname{SEM}(n=14)$

All data are calculated from peripheral progesterone concentrations measured three times a week.

There are no significant differences between groups.
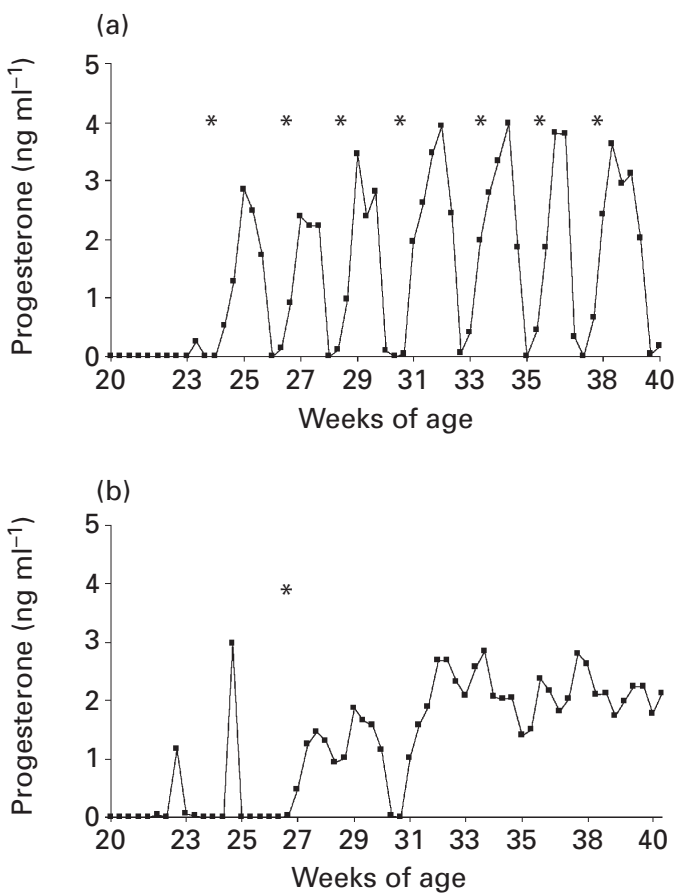

Fig. 3. Plasma progesterone concentrations measured three times a week in representative ewe lambs that showed (a) repeated ovarian cycles or (b) a persistent corpus luteum. *Indicates oestrous behaviour.

\section{Onset of puberty: male lambs}

Growth-restricted lambs tended to have lower plasma LH concentrations compared with normally developed male lambs for the first 6 weeks of life but this difference 

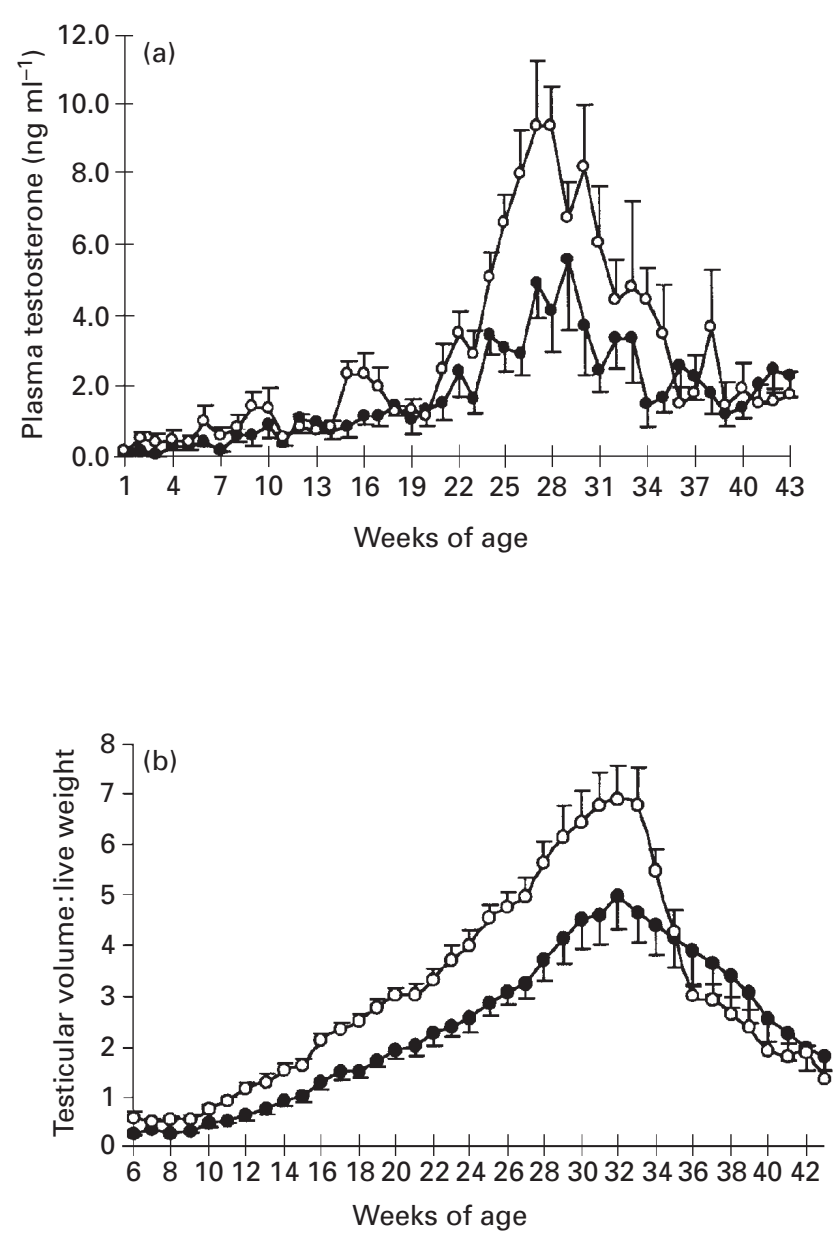

Fig. 4. Weekly (a) plasma testosterone concentrations and (b) testicular volume expressed as a ratio to live weight in growthrestricted $(0 ; n=7)$ and normally developed $(O ; n=7$ up to week 25 and $n=5$ thereafter) male lambs. Values are mean \pm SEM.

was not significant. Thereafter, there were no differences between the two groups (Fig. 2b).

Mean weekly plasma testosterone concentrations increased slowly before week 14 of age and then increased rapidly from week 15 to week 28 of age in male lambs of both groups (Fig. 4a). Testosterone concentrations began to diverge during the first 7 weeks of life between growthrestricted and normal male lambs with lower mean concentrations during this period in the growth-restricted group $(P<0.01)$. Thereafter, from weeks $8-14,15-20$ and 21-28 of age, overall mean testosterone concentrations were lower $(P<0.05)$ in growth-restricted lambs compared with normally developed male lambs. After this time, there were no significant differences in testosterone concentrations between the two groups during the remainder of the experimental period.

The onset of puberty, as indicated by the timing of the increase in plasma testosterone concentrations, occurred later $(P<0.005)$ in growth-restricted than in normally developed lambs (Table 3). The timing of the maximum
Table 3. Plasma testosterone concentrations, timing and magnitude of peak testosterone concentrations and of maximum testicular volume in growth-restricted and normal birth weight male lambs

\begin{tabular}{|c|c|c|}
\hline \multirow[b]{2}{*}{ Characteristic } & \multicolumn{2}{|c|}{ Nutritionally induced growth status } \\
\hline & $\begin{array}{c}\text { Growth-restricted } \\
\qquad(n=7)\end{array}$ & $\begin{array}{c}\text { Normal } \\
(n=7)\end{array}$ \\
\hline $\begin{array}{l}\text { Age at time of sustained } \\
\text { increase in testosterone } \\
\text { concentrations (weeks) }\end{array}$ & $22 \pm 1.0$ & $17 \pm 1^{* *}$ \\
\hline $\begin{array}{l}\text { Age at time of peak } \\
\text { testosterone concentrations } \\
\text { (weeks) }\end{array}$ & 27 & $27^{\mathrm{a}}$ \\
\hline $\begin{array}{l}\text { Peak value of testosterone } \\
\text { concentrations }\left(\mathrm{ng} \mathrm{ml}^{-1}\right)\end{array}$ & $5.8 \pm 1.1$ & $9.4 \pm 0.5^{* a}$ \\
\hline $\begin{array}{l}\text { Age at time of maximum } \\
\text { testicular volume (weeks) }\end{array}$ & $32 \pm 1$ & $30 \pm 2^{a}$ \\
\hline
\end{tabular}

peak of testosterone concentrations was identical in the two groups (week 27) but peak testosterone concentrations per se were lower $(P<0.05)$ in growth-restricted compared with normally developed lambs (Table 3).

There were no differences in live weight at the onset of puberty between growth-restricted and normally developed male lambs $(45 \pm 2$ and $48 \pm 1 \mathrm{~kg}$, respectively). Irrespective of nutritional treatment, the time of onset of puberty in male lambs was correlated negatively with birth weight $(r=-0.780, n=14, P<0.01)$. There was no significant correlation between peak testosterone concentrations and birth weight for the two groups ( $r=0.523, n=12, P>0.05)$. However, there was an association between live weight at the timing of maximum peak of testosterone concentrations and lamb birth weight $(r=0.617, n=12, P<0.05)$.

Testicular volume increased with age in both groups of lambs (Fig. 4b). Maximum testicular volume, expressed as a function of live weight, occurred at the same age (Table 3) but was lower in magnitude in growth-restricted compared with normally developed lambs (Fig. 4b).

One growth-restricted lamb had only the left testis inside the scrotal sac and was killed at the end of the experimental study (week 43 of age) to locate the right testis. It was found inside the abdominal cavity and was $38 \%$ smaller in mass compared with the left testis. Although spermatozoa were present in the epididymis of the left testis, no spermatozoa were present in the right epididymis.

\section{Discussion}

High maternal nutritional intakes throughout gestation in adolescent pregnant sheep resulted in rapid maternal 
growth rates and in significant reductions in both placental and fetal mass at term, which resulted in a significant delay in the time of onset of puberty in male but not in female lambs. These results are believed to be the first to relate maternal nutrition during pregnancy to the onset of puberty of the offspring.

The results demonstrate that nutritionally induced prenatal growth restriction is insufficient to delay first ovulation in female lambs when they are fed ad libitum after parturition. Growth-restricted spring-born female lambs (from high intake dams) reached puberty at a similar age and at equivalent live weights as normally developed female lambs. These results are consistent with an earlier study carried out at this latitude in which spring-born female lambs of a commercial genotype, raised on ad libitum feed intakes under natural photoperiod, reached puberty at week 27 of age and at a live weight of 35-45 kg (Adam et al., 1998).

In the present study, the high rates of live weight gain in both groups of female lambs meant that they had achieved the weight $(30-35 \mathrm{~kg}$ ) considered by some workers to be necessary to achieve puberty, by week 15 of age (Foster and Olster, 1985; Foster et al., 1989; Suttie et al., 1991). Thus, the data support the accepted premise that if female lambs have attained mature body size (energy balance) when photoperiodic cues are appropriate, they will initiate reproductive function (Foster, 1983).

This finding contrasts with studies investigating the response to severe undernutrition and restricted live weight gain after weaning (Foster et al., 1985; Adam et al., 1998) or maintenance on a low energy diet (Fitzgerald et al., 1982), which resulted in a delay or even failure to reach puberty. In the nutritionally restricted state, these animals are hypogonadotrophic owing to reduced LH secretion (Foster and Olster, 1985; Suttie et al., 1991) as a result of inadequate GnRH release (Foster et al., 1989; I'Anson et al., 1997). Furthermore, re-alimentation led to a rapid increase in gonadotrophin secretion and restored $\mathrm{LH}$ pulse frequency (Foster et al., 1985). These results indicate that postnatal nutritional and growth-related cues have a profound influence on the gonadotrophic drive governing initiation of ovulation in growing ewe lambs. Although $\mathrm{LH}$ pulse frequency was not measured in the present study, postnatal plasma LH concentrations were generally higher in growth-restricted than in normally developed ewe lambs. This finding indicates that the initial appropriate body growth observed in growth-restricted ewe lambs, despite the low live weight at birth, permitted the hypothalamicpituitary axis to initiate reproductive function at a comparable pubertal age. Alternatively, the trend towards higher LH concentrations may putatively reflect a lack of negative oestradiol feedback from the follicle-depleted ovaries, which are a feature of prenatally growth-restricted females in this model (Da Silva et al., 1998).

A limited number of studies have investigated the effects of maternal nutrition during pregnancy on the development of the hypothalamic-pituitary axis after birth. Borwick et al.
(1994) reported no effects on hypothalamic-pituitary activity (as measured by LH pulse frequency and amplitude and response to exogenous $\mathrm{GnRH}$ challenge) of female offspring born to mothers undernourished from day 100 of pregnancy. In contrast, female lambs born to mothers undernourished from day 30 of pregnancy showed impaired hypothalamic-pituitary function (decreased responsiveness to $\mathrm{GnRH}$ ) at day 55 of age (Deligeorgis et al., 1996), thereby indicating that undernutrition early in gestation may impair subsequent hypothalamic-pituitary function. However, in the study of Deligeorgis et al. (1996) there were significant treatment differences in postnatal live weight profiles that may confound prenatal versus postnatal effects. This finding is in contrast to the present study in which postnatal live weight gain was similar between groups.

Although prenatally growth-restricted female lambs had a similar capacity to respond to natural photoperiod and begin cyclical ovarian activity as normal birth weight lambs, this does not preclude the possibility of a longerterm impact on female reproductive performance. In parallel studies using the current adolescent model, follicledepleted ovaries were observed in fetuses from high intake dams at days 104 and 128 of gestation (Da Silva et al., 1998, 2000). Similarly, in humans, de Bruin et al. (1998) reported a major depletion of follicles in the ovaries of comparable growth-restricted fetuses. In addition, adolescent girls with low birth weight for gestational age had a smaller uterus and a reduced ovarian volume compared with girls born with an appropriate birth weight for gestational age (Ibãnez et al., 2000). The possibility of impaired reproductive organ development and exhaustion of follicle reserves during adult life may be more important for humans than sheep as their period of reproductive activity is much longer (Faddy et al., 1992; Te Velde, 1993). However, the observations of Gunn et al. (1995), who reported a reduction in reproductive performance of female sheep born to ewes undernourished during the last 100 days of pregnancy, support the concept that prenatal nutrient restriction may impact on adult reproductive function.

In the present study, the time of onset of puberty in normal birth weight males was comparable to the onset at weeks 16-18 of age recorded in Suffolk lambs (Olster and Foster, 1986). In contrast, the 5 week delay in the onset of puberty in growth-restricted male lambs indicates that nutritionally induced fetal growth restriction had a significant impact on the onset of sexual maturation. As both groups of male lambs were housed under identical natural lighting conditions, the magnitude of pubertal gonadal activation, as measured by mean peak testosterone concentrations and testis size, must have been regulated by nutritional or growth-related cues (before and after birth), while the timing of these events was influenced by photoperiod.

In the present study, growth-restricted male lambs were older than normally developed lambs at the onset of puberty, which occurred at similar live weights, thereby indicating that body weight per se is likely to be the major 
determinant of the time of onset of pubertal function in the current study. Several studies have reported that the level of nutrition and, hence, growth rate, during the prepubertal period can influence the timing of the onset of puberty (Foster et al., 1978; Lee et al., 1981; Adam and Findlay, 1997). Dýrmundsson (1973) reported that growing male lambs experiencing low nutrition attain puberty at an older age but at a lighter live weight than lambs reared on high nutrition. However, these effects were a response to a reduction in nutritional status imposed after birth and were associated with reductions in postnatal growth rates in lambs with similar birth weights. This finding contrasts with the present study in which the reduction in growth rates in growth-restricted male lambs originated largely from the nutritional treatments imposed on the mothers during pregnancy.

The delay in the postnatal activation of the reproductive axis in prenatally growth-restricted male lambs may be due in part to altered gonadotrophin secretion; the marked trend towards low LH concentrations (measured weekly) during the early neonatal period supports this hypothesis. Similarly, Foster et al. (1978) reported later onset of LH pulsatile secretion and delayed puberty in slowly growing male lambs compared with their rapidly growing lambs. A reduced $\mathrm{LH}$ response to exogenous $\mathrm{GnRH}$ has been reported in 8-week-old male lambs born to mothers undernourished from day 30 of pregnancy (Deligeorgis et al., 1996) and indicates that prenatal nutrition may programme postnatal hypothalamic-pituitary activity. This contention is supported by the observation that pharmacological inhibition of gonadotrophin secretion during the second half of pregnancy reduced plasma testosterone concentrations in lambs aged 28 weeks (Thomas et al., 1995). Reduced testicular size has also been observed in prepubertal lambs immunized against $\mathrm{GnRH}$ in which plasma FSH concentrations were particularly suppressed compared with control animals (Brown et al., 1994). Although plasma FSH concentrations were not measured in the present study, it is possible that lower FSH secretion in restricted lambs compared with normal birth weight lambs had a detrimental effect on Sertoli cell replication, thereby reducing testicular size in growth-restricted lambs. It has been demonstrated that hypophysectomy performed in 6week-old lambs reduced the number of Sertoli cells by $30 \%$ (Courot, 1967).

Similarly, in a parallel study using the adolescent model, we have demonstrated that placentally induced growth restriction in late gestation male fetuses is associated with attenuated pituitary gonadotrophin gene expression and perturbed testicular development (Da Silva et al., 1998). Thus, in the present study the effects on testicular growth and testosterone secretion in the male offspring may have resulted from combined effects of altered development of the hypothalamic-pituitary-testicular axis induced by nutrient deprivation prenatally and the persisting influences of prenatal nutrient restriction on postnatal body growth.

In conclusion, using the pregnant adolescent sheep model, it has been shown that prenatal growth restriction is not detrimental to the onset of puberty (defined as first ovulation) when female lambs are fed ad libitum after birth. In contrast, in male lambs, prenatal growth restriction delayed the onset and magnitude of sexual activation until live weights similar to those of normal birth weight males were achieved.

The authors thank T. Atkinson for carrying out the LH iodination, A. F. Parlow (NIADDK National Hormone and Peptide Program) for hormone preparations and antiserum, and M. Cruickshank for technical help with the radioimmunoassays. P. Da Silva was funded by the Boyd Orr Research Centre and Praxis XXI.

\section{References}

Adam CL and Findlay PA (1997) Effect of nutrition on testicular growth and plasma concentrations of gonadotrophins, testosterone and insulin-like growth factor I in pubertal male Soay sheep Journal of Reproduction and Fertility 111 121-125

Adam CL, Findlay PA, Kyle CE and Young P (1998) Effect of restricted nutrition on timing of puberty in female Soay sheep Journal of Reproduction and Fertility 112 31-37

Barker DJP, Winter PD, Osmond C, Phillips DIW and Sultan HY (1995) Weight gain in infancy and cancer of the ovary The Lancet 345 1087-1088

Borwick SC, Rhind SM and McMillen SR (1994) Hypothalamic and pituitary activity in prepubertal Scottish Blackface ewe lambs, undernourished before and after birth Proceedings of $45^{\text {th }}$ Annual Meeting of the European Association for Animal Production 278 (Abstract)

Brooks AN, Hagan DM, Sheng C, McNeilly AS and Sweeney T (1996) Prenatal gonadotrophins in sheep Animal Reproduction Science $\mathbf{4 2}$ $471-481$

Brown BW, Mattner PE, Carroll PA, Holland EJ, Paull DR, Hoskinson RM and Rigby RDG (1994) Immunization of sheep against GnRH early in life: effects on reproductive function and hormones in rams Journal of Reproduction and Fertility 101 15-21

Brown LM, Pottern LM and Hoover RN (1986) Prenatal and perinatal risk factors for testicular cancer Cancer Research 46 4812-4816

Chandrasekhar Y, D'Occhio MJ, Holland MK and Setchell BP (1985) Activity of the hypothalamo-pituitary axis and testicular development in prepubertal ram lambs with induced hypothyroidism or hyperthyroidism Endocrinology 117 1645-1651

Corker CS and Davidson DW (1978) A radioimmunoassay for testosterone in various biological fluids without chromatography Journal of Steroid Biochemistry 9 373-374

Courot M (1967) Endocrine control of the supporting and germ cells of the impuberal testis Journal of Reproduction and Fertility Supplement $\mathbf{2}$ 89-101

Da Silva P, Aitken RP, Brooks AN, Rhind SM and Wallace JM (1998) Perturbed pituitary gonadotrophin gene expression and gonadal development in growth restricted fetal lambs at day 128 of gestation Journal of Reproduction and Fertility Abstract Series 2210 (Abstract)

Da Silva P, Aitken RP, Rhind SM and Wallace JM (2000) The effect of nutritionally-mediated placental growth restriction on fetal pituitary gonadotrophin gene expression and gonadal morphology at day 104 of gestation Journal of Reproduction and Fertility Abstract Series 25265 (Abstract)

De Bruin JP, Dorland M, Bruinse HW, Spliet W, Nikkels PGJ and Te Velde ER (1998) Fetal growth retardation as a cause of impaired ovarian development Early Human Development 51 39-46

Deligeorgis SG, Chadio S and Menegatos J (1996) Pituitary responsiveness to $\mathrm{GnRH}$ in lambs undernourished during fetal life Animal Reproduction Science 43 113-121

Depue RH (1984) Maternal and gestational factors affecting the risk of cryptorchidism and inguinal hernia International Journal of Epidemiology $13311-318$ 
Dýrmundsson ÓR (1973) Puberty and early reproductive performance in sheep. II. Ram lambs Animal Breeding Abstracts 41 419-427

Faddy MJ, Gosden RG, Gougeon A, Richardson SJ and Nelson JF (1992) Accelerated disappearance of ovarian follicles in mid-life: implications for forecasting menopause Human Reproduction 7 1342-1346

Fitzgerald J, Michel F and Butler WR (1982) Growth and sexual maturation in ewes: dietary and seasonal effects modulating luteinizing hormone secretion and first ovulation Biology of Reproduction 27 864-870

Foster DL (1983) Photoperiod and sexual maturation of the female lamb: early exposure to short days perturbs oestradiol feedback inhibition of luteinizing hormone secretion and produces abnormal ovarian cycles Endocrinology 112 11-17

Foster DL (1994) Puberty in the sheep. In The Physiology of Reproduction Eds E Knobil and JD Neill pp 411. Raven Press Ltd, New York

Foster DL and Olster DH (1985) Effect of restricted nutrition on puberty in the lamb: patterns of tonic luteinizing hormone (LH) secretion and competency of the LH surge system Endocrinology 116 375-381

Foster DL, Mickelson IH, Ryan KD, Coon GA, Drongowski RA and Holt JA (1978) Ontogeny of pulsatile luteinizing hormone and testosterone secretion in male lambs Endocrinology 102 1137-1146

Foster DL, Yellon SM and Olster DH (1985) Internal and external determinants of the timing of puberty in the female Journal of Reproduction and Fertility 75 327-344

Foster DL, Ebling FJP, Micka AF, Vannerson LA, Bucholtz DC, Wood RI, Suttie JM and Fenner DE (1989) Metabolic interfaces between growth and reproduction. I. Nutritional modulation of gonadotrophin, prolactin, and growth hormone secretion in the growth-limited female lamb Endocrinology 125 342-350

Francois I, de Zegher F, Spiessens C, D'Hooghe T and Vanderschuren D (1997) Low birth weight and subsequent male subfertility Pediatric Research 42 899-901

Gunn RG, Sim DA and Hunter EA (1995) Effects of nutrition in utero and in early life on subsequent lifetime reproductive performance of Scottish Blackface ewes in two management systems Animal Science $\mathbf{6 0}$ 223-230

Hay WW, Jr (1998) Etiologies of preterm birth: intrauterine growth restriction Prenatal Neonatal Medicine 3 121-124

I'Anson H, Terry SK, Lehman MN and Foster DL (1997) Regional differences in the distribution of gonadotrophin-releasing hormone cells between rapidly growing and growth-restricted prepubertal female sheep Endocrinology 138 230-236

Ibãnez L, Potau N, Enriquez G and de Zegher F (2000) Reduced uterine and ovarian size in adolescent girls born small for gestational age Pediatric Research 47 575-577

Jones ME, Swerdlow AJ, Griffith M and Goldacre MJ (1998) Prenatal risk factors for cryptorchidism: a record linkage study Paediatric and Perinatal Epidemiology 12 383-396

Judd SJ (1998) Disturbance of the reproductive axis induced by negative energy balance Reproduction, Fertility and Development 10 65-72
Lee VWK, Bremner WJ, Cumming IA, de Kretser DM and Findlay JK (1981) Effects of LH-RH infusion, castration and cryptorchidism on gonadotrophin and testosterone secretion in developing rams Journal of Reproduction and Fertility Supplement $30111-118$

McNeilly AS, Jonassen JA and Fraser HM (1986) Suppression of follicular development after chronic LHRH immunoneutralization in the ewe Journal of Reproduction and Fertility 76 481-490

Møller H and Skakkebæk NE (1997) Testicular cancer and cryptorchidism in relation to prenatal factors: case-control studies in Denmark Cancer Causes and Contro/ 8 904-912

Olster DH and Foster DL (1986) Control of gonadotrophin secretion in the male during puberty: a decrease in response to steroid inhibitory feedback in the absence of an increase in steroid-independent drive in sheep Endocrinology 118 2225-2234

Robinson JJ, Sinclair KD and McEvoy TG (1999) Nutritional effects on foetal growth Animal Science 68 315-331

Ronayne E and Hynes N (1990) Measurement of plasma progesterone concentrations by extraction and non-extraction radioimmunoassays Irish Journal of Agricultural Research 29 109-115

Russel AJF, Doney JM and Gunn RG (1969) Subjective assessment of body fat in live sheep Journal of Agricultural Science Cambridge 72 451-454

Sharpe RM and Bartlett JM (1985) Intratesticular distribution of testosterone in rats and the relationship to the concentrations of a peptide that stimulates testosterone secretion Journal of Reproduction and Fertility $74223-236$

Suttie JM, Foster DL, Veenvliet BA, Manley TR and Corson ID (1991) Influence of food intake but independence of body weight on puberty in female sheep Journal of Reproduction and Fertility 92 33-39

Te Velde ER (1993) Disappearing ovarian follicles and reproductive ageing The Lancet 341 1125-1126

Thomas GB, McNeilly AS and Brooks AN (1995) Effect of suppression of pituitary-testicular function during foetal life with a GnRH agonist on reproductive development in ram lambs during the first 28 weeks of life Journal of Reproduction and Fertility Supplement 49 533-537

Wallace JM, Aitken RP and Cheyne MA (1996) Nutrient partitioning and fetal growth in rapidly growing adolescent ewes Journal of Reproduction and Fertility 107 183-190

Wallace JM, Da Silva P, Aitken RP and Cruickshank MA (1997) Maternal endocrine status in relation to pregnancy outcome in rapidly growing adolescent sheep Journal of Endocrinology 155 359-368

Wallace JM, Bourke DA, Aitken RP and Cruickshank MA (1999) Switching maternal dietary intake at the end of the first trimester has profound effects on placental development and fetal growth in adolescent ewes carrying singleton fetuses Biology of Reproduction 61 101-110

Received 5 February 2001.

First decision 9 March 2001.

Accepted 9 May 2001. 